\title{
COOPERATION PLANS BETWEEN SOE AND NKVD REGARDING THE ROMANIAN AREA DURING JANUARY-MAY 1944
}

\author{
Marian ZIDARU \\ Black Sea House Association, Constanța, Romania \\ marian.zidaru@yahoo.com
}

\begin{abstract}
The main S.O.E aim seems to have been the utilization of political circles in an endeavour to overthrow the government and get Romania out of the war or at least to bring about the removal of its array from the Russians front, and to deny the national resources to Germany. The USSR has been constant in its disinclination to play with Maniu or associates itself with British planes until they are convinced that some concrete contribution at their war aim would results. They would however be ready to discuss unconditional surrender with the emissary of the Romanian government, capable of putting it into effect. The evolution of these SOE plans will be presented in this article.
\end{abstract}

\section{Keywords: SOE, NKVD, Romania, Antonescu, Maniu}

\section{Introduction}

SOE and NKVD had an operative base in Romania made up of agents and collaborators. At a meeting, S.O.E. Foreign Office in February 1941, the representatives of S.O.E. informed that after the departure of the members of the Bucharest diplomatic mission, their program in Romania depended on cooperation with Maniu and the Christian Democrat circles. One of the most important Soviet agents in Romania was Emil Bodnaras. He was arrested by the Siguranta and settled in Braila.

Bodnaras travelled freely, to Bucharest and to Targu-Jiu. He met Gheorghiu-Dej who on 4 April have instructed Patrascanu, Bodnaras, and Ion Gheorghe Maurer to join the other political parties to overturned the Antonescu government [1].

On the 3rd July 1942, the talk between S.O.E. with the N.K.V.D. took place in London regarding coup d'état, and the Anglo-Russian guarantee asked for Iuliu Maniu Bessarabia and Bukovina. The N. K.
V. D. representative said that they saw no difference between the policies of Antonescu and Maniu and that in fact what the Romanians want to be a guarantee from Russia that the latter would give to Romania a large slab of Russian territory in return for a vague promise that a successful coup d'état would be brought about.

After 2 weeks an S.O.E. representative lunched with the N. K. V. D. representative and it was pretty clear that they have received an answer from Moscow and that the answer was definitely no. [2] SOE sent the Ranji team to Romania in 1943. The head of the mission, major David Russell, was killed and the wireless operator Turcanu escaped and arrived in Bucharest. After his arriving to Bucharest in autumn 1943, he was given shelter by friends and began transmissions for Maniu. Police contacts warned him whenever German traits followed him, but on 10 July 1944, Abwehr located him and he was arrested by Romanian police. He has hidden his radio and recovered it after 23 August, using it, to 
communicate with the Americans who sent bombers to attack German positions at Otopeni airfield on 26 August [3].

Another team sent by SOE to Romania was composed of Lt-Col by Chatelain, Major Ivor Porter, and Captain Silviu Metianu. Chatelain and his party had many relationships in the political world in Bucharest. But they were arrested by the Romanian Police when they were parachuted in the wrong place [4].

In early February, Pravda strongly attacked the deployment of the Chastelain team to Romania. On 6 February, Ambassador Clark Kerr wrote to the Head of SOE: "From one or two fairly high up Soviet officials we have had more than half a hint that stupid Pravda article which caused such a to-do last month was due, in part at any rate, to the dropping of those three officers in Romania gather from the Foreign Office that the dropping happened on December 2nd and that the Russians were not told until some days later. As the main brunt of the war against Romania has fallen upon the Russians, they are sensitive about that country, and I suggest that if any such operation is contemplated again it might be prudent to let them know beforehand and thus forestall trouble"[5].

\section{Peace negotiations in Cairo}

On 29th February 1944, an SOE report noted that one of Maniu's delegates (Constantin Visoianu) who was expected to land by plane on Cyprus Sunday has not arrived. Prince Stirbey was reported to be due in Istanbul. arrangements are being made for his secret onward journey to Cairo. Maniu's emissary price Stirbey arrived in Istanbul on march 1st. His mission primarily informative but endorsed not only by Maniu and Antonescu but also by the king and the Romanian communist party should his inquiries disclose conditions likely to be acceptable he will be invested with authority to negotiate and Romanian military attaché Ankara and former M.A Budapest would be attached to assist working out details of Romania's military co-operation with allied nations. Stirbey states Romanians not willing to surrender to Russians alone but prepared to capitulate to the British; even though it was only to a token force in form of a parachute battalion; when endorsing mission pointed out it would in their opinion be useless until Stirbey could promise prompt action against Germans. Arrangements being made for secret onward transmission of Stirbey to Cairo for discussions with representatives of allied, none of above details to be communicated to Russians without prior consultation British ambassador.

The first meeting in Cairo of allied representatives with Stirbey went off better than expected and the ambassador believed it might be considered the basis for further discussions. Full details telegraphed by the ambassador to SOE leader. It noted that any indication as to Russian reactions would be welcome.

Romanian government decided not to defend the Dniester; any opposition will be by Germans only.

In reply to the request by Antonescu for advice on what to do regarding Hitler's summons to his H.Q. general, Wilson telegraphed that acceptance invitation would be considered by the British as final evidence of Romanian collaboration urged immediate surrender to the allied nations.

When Soviet troops entered Romania, Soviet Foreign Minister Viacheslav Molotov released a statement saying that The Soviet Union 'does not pursue the aim of acquiring Romanian territory or of altering the existing social structure of Romania [6].

In reaction, the German Minister of Foreign Affairs, Joachim von Ribbentrop, characterized publicly the Molotov's declaration, as insincere and underlined the danger the Soviets represent for Romania [7]. On 2 April 1944, de Chatelain was taken to see Maniu. Maniu informed him that he had disclosed the existence of the 'Reginald' transmitter to the Romanians the reason for doing so was not clear - and 
it was this set that was used to send Antonescu's message. Antonescu's tolerance and use of the channel with Cairo underlined the significance to the British of the line of communication offered by the SOE presence in Romania. In psychological terms, it provided an enormous boost to active opponents of the Antonescu regime, principally Maniu and King Michael, but in political ones, it shed no light on the intentions of the Western Allies towards Romania.

Although Bucharest affirms that two Antonescu returned from Hitler HQ. without having undertaken fresh commitments, peace negotiations are being drawn out by Romanians under various pretexts. No reactions received as yet to the most helpful Molotov declaration.

W/T contract resumed on April 13th. Armistice terms sent in but no answer yet received. George Boxshall has again come on air but contracts interrupted for the second time as a result of the bombing of Bucharest on night 16th. Further W/T set has been infiltrated.

W/T resumed on April 20th. No answer to peace terms yet received but a long telegram from Maniu showed a desire to bargain and a total lack of understanding of real facts. To this sent very balanced but in spite of this unlikely Maniu will prove of further value. From a psychological point of view, the British bombing was in SOE view ill-timed. Russians seem to agree and have exploited position on their radio stating quote. They do not bomb civilian objectives.

In a telegram from April 18th SAM considered as regard Romania two alternative situations were envisaged: A Rumanian surrender or a continuation of the war in alliance with Germany. SAM'S signal seems to encourage the idea that a Romanian SOE mission might be acceptable to the Soviets even without a volte-face. London requested SAM for further information on this point.

In the meantime, answering the London point of confirmation that one of the main objects of a Romanian SOE mission in Russian-occupied Romania would be to recruit agents for infiltration into of additional agents from liberated Romanian territory.

All British past efforts to find suitable both in Cairo and in America have failed almost entirely owing to lack of suitable bodies [8]. London would like to have SAM's view regarding Soviet NKVD agreeing to a Rumanian SOE mission in Russianoccupied Romania in the event of the Romanians continuing to fight on the side of the axis.

If they agree Cairo should very much be liked to send a small SOE mission from here. SOE has in mind a mission of say 2 British 1 American officer $1 \mathrm{w} / \mathrm{t}$ operator (British) an American reserve $\mathrm{W}+\mathrm{T}$ operator. London should like to send major Boxshall as leader of the party.

In the event of a Romanian surrender this SOE/OSS mission could no doubt join with the British American missions' which would be sent to Romania.

OSS have so far not been approached had but suggest they should be invited to participate. Assume London will take up this hatter with the British ambassador in Moscow after hearing SAM's view [8]. In the SOE vision, this team follows to cooperate with NKVD to infiltrated paramilitary in German-occupied Romania in the case that Germans are withdrawn to the line of Transylvanian mountains. In SOE London opinion this would have a great advantage for recruitment agents and reciprocal facilities for infiltration from NKVD [9].

On April 14th, 1944 SAM informed that from the tone of Russians replies at SAM suggestions of terms of armistice with Romania and acceptance by them of all British amendments. London concluded that Russians will give the British all the facilities similar to those accorded them to Yugoslavia. SOE's proposal was to send a mission composed of SOE personal or one in which SOE is represented. Such a mission would do best to proceed in 
uniform. SOE considered it was of utmost importance that British Ambassador at outset should inform Molotov that the above British missions were designated for Romania and ask that Russians military authorities should be directed to give them all necessary aid. SAM was instructed to inform NKVD what SOE proposed to do and to ask NKVD to arrange with Russian military authorities in Romania to afford British mission cooperation every assistance. SAM was most anxious to work closely with SOE Romania to be able to visit it at all and members of that mission to Moscow [10].

At the request of SOE MIDEAST, Brigadier Hill was asked in April 1944 to consider the likelihood of the Soviet Authorities agreeing to a Romanian SOE/OSS Mission proceeding to Russian Occupied Romania. SOE MIDEAST were anxious to collaborate whit the Russians but felt that the inclusion of Russians in the first party would make the task difficult on account of the feeling in Romania whit regard to the Russians. Although this information was passed to NKVD, they informed Brigadier Hill that they did not wish to attach Russian personnel to these Missions [11].

On April 22nd, 1944 general George Hill had a long discussion with general Ossipov which was conducted in cordial. He evinced concern and what appears to be genuine hurt feelings at fact that S.O.E and O.S.S had not invited in N.K.V.D. to participate in a common operation.

He asked why they were excluded when both British and American organizations had professed desire to co-operate with N.K.V.D. with Red Army pressing into Romania Russian authorities are even more concerned to exploit every possibility of sabotage revolt etc than the British and Americans.

Ossipov then reverted to the original dropping of SOE agents in Romania in December 1944 with the charge that why had not conferred with N.K.V.D. and that dropping agents in uniform "seemed very strange. "

Nor could he understand the present proposal dropping 18 agents in uniform. Had British and Americans some private conversation he showed a jealousy one associates with love swain.

Hill explained that dropped agents in uniform:

A) To safeguard them from being treated as spies

B) that in a country which in the state on Romania many persons sympathetic to allies may be encountered these nights heisted to give shelter to spy. but not to soldiers in uniform

C) that when it comes to open negotiation for a volte-face on part of Romania. open presence of some allied officers in uniform might be of advantage.

Ossipov observed that German intelligence was very much in control of Romania. and had forced all over? the country was they, the Germans obligingly going to an eye? was there an understanding with Germans on the matter? Hill replies that his questions seemed to be absurd and quite off the mark. Hill then? raised the question of furnishing British and American personnel with some identity document to be used in the event of their falling in with Soviet forces advancing into Romania. Ossipov said he did not see how Russian authorities could issue such papers when information concerning the whole operation available to them was so scant. Is it too late at this stage to invite N.K.V.D to attach one of theirs to each of the six groups?

Hill thought it doubtful that they would have 18 men available but they may have a few. there are obvious advantages in British making offer which should reduce their suspicions.

On $24^{\text {th }}$ April, British and Americans reached to a general agreement along following lines:

Irrespective of the military situation they go ahead with the infiltration of six SOE/ OSS teams. Moscow was informed by Foreign Office. Teams are briefed by British 
ambassador in Cairo and Novikov asked for letters of recommendation. These teams will be the spearhead of British work and will try to recruit. SOE Cairo attach SOE officers and communications to any British mission which may go to Russian- occupied Romania.

SOE continued efforts simultaneously to penetrate enemy-occupied territory through Yugoslavia with Tito 's help.

However, it appeared Russians not likely to help western allies unless we ask for their collaboration. From a purely Romanian point of view this not desirable, since Romanians, in general, would tend to welcome Anglo/ British personnel but to resent Russians. But from a wider aspect prospect offered for collaboration with $\mathrm{N} \mathrm{K}$ $\mathrm{V}$ D most encouraging and might well afford a foundation for the development of collaboration elsewhere.

To avoid previous difficulties, SOE was very anxious that the soviet should be informed of SOE project. SOE did not at that stage propose asking for the inclusion of Russian officers in the missions: indeed, SOE were not suggesting. That this was done as we felt and still feel that such inclusion would make the task of first repeat the first contact with collaborators most difficult knowing especially from more recent reports the feeling there is in Romania at present in regard to Russians. once resistance groups have been successfully contacting however it would be desirable in every way to have Russian colleagues in British mission.

There was of course no private or secret arrangement made with anybody in Romania to drop personnel in uniform least of all with Romanian authorities. British only reason was to protect SOE personnel in the event of their capture upon landing.

This has been British usual practice in this theatre. Once contact has been established with resistance groups, SOE felt that this might be an advantage. The advantages of being in uniform in the event of a volte-face were evident.
In a telegram on April 24th, SOE Cairo wrote: It was clear that the necessity of obtaining the Russian benevolent cooperation in connection with the above has been fully realized but it appears to me that the method of securing it has been a very unfortunate one. Before broaching this subject, we should have ascertained whether or not it was advisable and feasible from the British point of view to include the Russians and to send to Romania a mission consisting of S.O.E, O.S.S, and N.K.V.D in line with the generally accepted policy, to negotiate peace terms with Romania on a concerted three-power basis.

If for some reason this would not be acceptable it ought to have been clear to anybody who knows the Russian mentality that the idea of leaving them out of the picture would not only fail to gain for us the assistance, we are seeking but would give rise to further suspicions instead.

To avoid this and to secure their cooperation, the case should have been presented to N.K.V.D that a purely British Mission was about to proceed and to invoke the terms of the Charter which provides for mutual assistance in sending agents into Axis occupied territories without compelling either of the signatories of the agreement to disclose any detail as to the purpose of such infiltration.

On the other hand, if there would have been no objection to including the Russians, SOE should have, instead of just informing them to participate in the operation and thus force their hand to give the mission their fullest support. British gesture no doubt would have been greatly appreciated had it been properly timed and would have gone a long way towards the improvement of their relations with the N.K.V.D. This invitation, however, should have come from SOE at an earlier stage and under no circumstances from O.S.S.

It appears that SOE have again allowed the events to overtake them and failed to cash in on a very favorable situation that might never reoccur.

In a telegram from April $29^{\text {th }}$, SAM 
announced to Force 133 that NKVD did not want to attach Russian agents to SOE Romanian missions they trust the offer will remain open. For SOE this was most satisfactory. NKVD did not concur with desirability put forward not a satisfactory proposal.

Submitted useless hope for official credentials from Russians while a concurring letter from high Russian authority would be preferable consider a document typewritten in Russian of official paper starting mission of bearer together with photograph signature etc. [12].

Following received by Prime Minister from M. Molotov. As is known, at the end of 1943 the British authorities sent to Romania several British subjects who since that time have maintained the connection with Marshal Antonescu and who have been referred to in the press as English parachutists. Although these persons are, it seems, considered to be prisoners of war of the Romanian Government, this British mission has its own radio station which it uses for cipher correspondence with the British representatives in cipher correspondence in Cairo. It is likewise known that the Romanian representative in Cairo, Stirbey, uses this same radio station and ciphers for communication with Maniu and Antonescu. Among these British subjects, there is the former director of the Romanian oil company "Unirea", the British officer do Chatelain, and also a former employee of the large English oil refinery at Ploesti, the British officer Porters, and a British subject of Romanian origin the officer Metianu. The lively political correspondence which is conducted with the help of this British group between Bucharest and Cairo bears witness to the fact that the Antonescu Government co-operates with it in this activity. Such a position could not exist otherwise than as the result of a definite agreement between the British Government and the Government of Romania.

I consider it necessary to draw your attention to the fact that the Soviet
Government has not been officially informed by the British Government either about such an agreement or about the presence in Romania of the British mission with Marshal Antonescu, just as it has not been informed about the tasks and aims of the activities of this British mission. The Soviet Government expects an explanation from the Government of Great Britain on this question.

The Soviet Government considers it all the more necessary to draw your attention to this because of the presence in Romania with Marshal Antonescu of a British mission whose purposes are unknown to the Soviet Government and at a time when Romania together with Germany is waging war against the Soviet Union, can only encourage the Government of Antonescu and can in no way contribute to hastening the capitulation of Romania and the acceptance by the Romanian Government of the Soviet armistice conditions which have been agreed the British and American Governments.

An SOE rapport considered that the accusation contained in this message is utterly baseless and can only be due to deliberate misunderstanding. Reply giving the true facts of the situation was to be sent SAM as soon as possible.

2. Meanwhile it would probably be best to suspend for the time being the infiltration into Romania of further O.S.S.-S.O.E. missions. London requested that SOE Cairo should suspend action on a common mission in Romania and until the matter was cleared up refrain from discussing the question any further with M. Molotov [13]. London instructed Cairo to suspend the dispatch of missions pending clarification of Molotov's message to the Prime Minister. As the ambassador has taken up the whole matter on the highest level, it was necessary SAM should in the meantime exercise great caution in anything they tell the Russian opposite number concerning SOE Romanian Mission [14].

OSS has been advised by general Deane from Moscow that Russians are very upset 
over the lack of invitation to them to be included in certain OSS/SOE missions shortly to be sent to Romania. OSS, being incompletely informed, replied to the effect apportioned projects for Romania did not constitute a formal joint mission but were in nature penetration teams primarily for intelligence purposes and without implications of a political nature. It was also added that while there would be a collaboration between British and Americans with regard to personnel. Joint action was not considered helpful in such types of intelligence activity. The resultant intelligence would be help at disposal of all united nations including Russia. They repeated both their messages to OSS Cairo who now advises that SOE has already invited Russians to join but that anticipated missions can easily be exclusively British and American. Cairo asks London to advise soonest what was the latest position in the order they may be able to assist OSS inputting general Deane straight [15].

\section{SOE ceased operation in Romania}

Foreign Office has vetoed infiltration of further missions as a result of the attitude taken up by Molotov with regard to de Chatelaine and SOE's other activities.

After this incident SOE focus on the extraction of the Autonomous team. In 1944, Tozan received instructions from his contacts in the SOE to try to escape De Chastelain [16].

Tozan informed SOE that as far as the Chatelain is concerned, Tozan stated that an exchange of prisoners could be made immediately and that Mihai Antonescu was only waiting for the British Government's agreement on the exchange. Tozan said the person proposed to be changed for Chastelain was a Romanian captain with a $\mathrm{W} / \mathrm{T}$ device in Cyprus. So, it was obvious that Mihai Antonescu did not tell Tozan that the SOE transmitted to the Romanian government through Gane suggesting this identical change [17].

Regarding the place and means of exchanging prisoners, Tozan was a little vague and said such matters were only detailed questions, while he was only interested in the main issue. At another meeting, Tozan and Masterson said the exchange could only be done after returning to Romania. After the conversation, Boxshall and Masterson were more than ever convinced that Mihai Antonescu kept Chastelain as a means to obtain favourable conditions with the allies. After this interview with Tozan, the impression he gained was that he was clearly sent by Mihai Antonescu to contact the allies and to secure for Mihai Antonescu favourable conditions after the war, regardless of the government that might be in power in Romania.

Tozan was also interested in this possible combination, given his earlier requests to the SOE to pay Malaxa or its protectors in Istanbul against the Romanian lei.

Boxshall and Masterson were of the opinion that Tozan knew much more than he was willing to disclose and used this as a lever to go to London with Mrs. Stircea. He also said that although he was in no way intending to threaten, he considered it justified to seek other contacts with the allies if he could not obtain results through both Boxshall and Masterson.

In these connections, the SOE considered it interesting that Maniu expressed his disbelief with Antonescu, saying that no plan presented to them should be seriously considered by the British [18].

\section{Conclusion}

In early 1944 SOE Cairo should very much like to send a small SOE mission in Romania.

SOE have in mind a mission of 2 British officers, an American officer, $1 \mathrm{w} / \mathrm{t}$ operation (British) and an American reserve $\mathrm{W}+\mathrm{T}$ operator.

London should like to send major Boxshall as leader of the party.

In the event of a Romanian surrender this SOE/OSS mission could no doubt join with the British American missions' which would be sent to Romania. 
One of the main objects of a Romanian SOE mission in Russian occupied Romania was to recruit agents for infiltration into of additional agents from liberated Romanian territory.

The NKVD declined to participate in such a mission and the plan has been abandoned.

\section{References List}

[1] Ioan Hudiță (1994), 'Pagini de Jurnal', Magazin Istoric, Vol. 28(7).

[2] Zidaru Marian, (PDF) The New Research Regarding Cooperation between S.O.E. N.K.V.D. During WWII. Available from: https://www.researchgate.net/publication/343553340_The_New_Research_Regarding Cooperation_between_SOE_-_NKVD_During_WWII [accessed Apr 10 2021].

[3] Dennis Deletant, British Clandestine Activities in Romania during the Second World War, p. 210.

[4] Ivor Porter, Operatiunea Autonomous in Romania pe vreme de razboi [Operation Autonomous with SOE in wartime Romania], Bucharest, Humanitas, 2008, p. 219.

[5] PRO Kew Gardens HS 5/154, Cipher telegram from Moscow Archibald CLARK Kerr to major general Colin Gubbins, British embassy, Moscow. Telegram from 6th February 1944.

[6] Florin Constantiniu, "România intre 1944 si 1989," Stephen Fischer-Galati, Dinu C. Giurescu,

[7] Ioan-Aurel Pop (coord.), O istorie a Românilor, Cluj-Napoca, Fundatia Culturală Română, 1998, p. 300.

[8] Romania in anticamera Conferintei de Pace de la Paris. Documente, [Romania in the antechamber of the Peace Conference of Paris. Documents], Bucharest, Arhivele Nationale ale României, 1996, p. 448;

[9] PRO Kew Gardens HS 5/154, Various notes.

[10] Ibid., To Massingham for speedwell 1492(1482,) sent Istanbul 2807(2807) send to Moscow 60(60) form France 133 Following for DH

[11] [11] Ibid., Massingham for speedwell 1461024810 RPTD for some 105010563 rptd Istanbul 2806028062 RRTD London 987633145

Reference SAMS's signal quoted in tribe 4560645602 of 150153

[12] Ibid., Various telegrams 8.4.44. London to Cairo; Telegram from 29.4.44 Speedwell 2068 FORCE 1333129 IMMEDIATE TO Force 133 ONLY from Foreign Office to Moscow No. 1311 D.S.40 p.m. 30th April, Immediate to Moscow only. with reference to our 3433 Concerning Romania. Cipher tel to MOSCOW 3438 1.5 SNE Repeat Force 133, $8148 \quad$ CAW Cypher tel from New York. DESP 1953 2.5.44. RECD 0455 3.5.44. COM 738 Reference ZP Telegrams to Moscow 1129 and 87 RPTD Washington 3192 and 182.

[13] Ibid, SOE/OSS/NKVD Liaison in Romania

[14] Ibid, HS 154. Various notes.

[15] Ibid, Cipher telegram to Moscow 10. 5. 44.

[16] Ibid, HS 5/833 Agents, and collaborators, Ianos@Visoianu, Force 133 report from 28 May 1944

[17] Ibid, SOE Report „Pants” from 29th July 1944, signed by DH/5, p. 1-3

[18] Ibid, SOE reports from Istanbul July 20 . signed by D/H44 